Equities (San Francisco, CA), who believes, based on independent legal advice, that TKT/HMR's gene-activated EPO does not infringe any of Amgen's patents. Their conclusions stem, in part, from a fundamental patent law rule holding that "natural products" cannot be patented. Since gene activated EPO can be made without ever touching a cell's endogenous $\mathrm{IPO}$ gene, 'T'K'T/HMR expect the court to conclude that gene-activated EPO is natural, unpatentable, and outside the scope of Angen's (or presumably anyone else's) patents. The answer here may not be clear cut; a court could consider geneactivated $\mathrm{EPO}$ to be identical to native $\mathrm{EPO}$, yet nomnatural.

Perhaps a more pressing issue is whether gene activated EP() has givcosylation that

\section{Gene activation and EPO}

Gene activation is potentially very important because it provides an alternative method for producing proteins that are not covered by product patents. When some of the older patents on recombinant protein expire, it may be a way to produce generic versions. Bone marrow stimulating erythropoeitin (EPO) has become an early gene activation target because the potential rewards are huge and because the product patent coverage on the protein seem complex; and where there is complexity, there is usually room for doubt.

Gene activation techniques have been developed independently by several companies: Transkaryotic Therapies (Cambridge, MA), Cell Genesys (Foster City, CA), Ares Serono (Geneva), and probably others, too. Gene activation depends on the fact that most human genes are present in most human cells, but frequently only in an inactive or almost inactive form. The gene for $\mathrm{EPO}$, for instance, is present in the majority of cell types, but it is only significantly active in certain kidney cells. That activity can be changed using homologous recombination to insert a new regulatory region to change the pattern of gene expression. The regulatory region consists of a targeting region and the new regulatory elements themselves.

It will take patent lawyers (and more legal proceedings) to unravel the differences between the various types of gene activation. TKT patents and literature, for instance, exert claims to ownership of methods in which regulatory regions are inserted to increase expression of a gene, to reduce or eliminate it, or to introduce amplifiable sites, thereby making cells that can produce large quantities of a protein. The Ares Serono technology, as described by Gianpiero DeLuca, head of the patent department, sounds very similar in outline-new regulatory sequences used to differs from uEPO. Amgen claims "upon information and belief" that the glycosylation of gene activated EPOs differs from uEPO. UBS Securities and Pacific Growth Industries, however, report that it does not.

Finally, in their reports, both UBS Securities and Pacific Growth Industries concluded that Amgen's '698 and '080 patents are invalid. The ' 698 patent that apparently covers gene-activated EPO is thought to be invalid because it does not describe how to produce gene-activated EPO, nor was it "obvious" in 1983, the effective filing date of the patent. The ' 080 patent is thought to be predated by several 1982 publications that disclose the production of EPO from nonhuman urine.

\section{Ken Chahine}

activate, downregulate, or amplify gene any gene of interest. The strategy of Hoechst Marion Roussel (HMR; Kansas City, MO) in gene activation also reflects a certain similarity in the approaches. HMR has gene activation partnerships with both TKT and Cell Genesys, collaborations that began in 1996 and March 1997, respectively. Furthermore, it began a collaboration in March 1997 with Oncogene Science (Uniondale, NY) to develop orally active small molecule inducers of EPO gene expression, an agreement that HMR says is "complementary to the major gene-activated erythropoietin therapeutic program."

Of the major pharmaceutical companies, HMR and Boehringer Mannheim (Mannheim, Germany) are, seemingly, taking gene activation seriously. Boehringer Mannheim is collaborating with Ares Serono to produce gene-activated EPO, a process that is "at the industrial scale-up stage," according to Ares' DeLuca. Boehringer Mannheim currently markets EPO- $\beta$ (Amgen's EPO is $\alpha$ ) outside the United States.

Cell Genesys also licensed its gene activation to Organon (Hamburg, Germany), an Akzo subsidiary, for the production of follicle-stimulating hormone (FSH), although an Organon spokesperson said the company was no longer involved in gene activation. In any case, according to Ares Serono's spokesperson, Christophe Lamps, the use of gene activation would not have released Organon from its obligation to pay royalties to Serono on worldwide sales of FSH. "[Gene-activated FSH] should still fall under our own patents," he claims.

All this convergence should keep many lawyers employed. According to DeLuca, "In a market of a billion dollars, further lawsuits are inevitable."

Sylvia Davidson
Recover

\section{High Secretors or Rare Cells...}

ENRICH cell lines.

SCREEN cells directly after fusion or transfection.

MONITOR cell populations.

INCREASE protein recovery.

REDUCE labor and plating.

SHORTEN product development timelines.

USING GEL MICRODROPS -

- Encapsulate single cells

- Capture secreted protein

- Quantitate fluorescence

- Sort high secretors using FACS

TO GET STARTED,

YOU NEED -

A cell line of interest and labeled antibody pairs for sandwich assay.

YOUR PLACE OR OURS Lease the CellSys Microdrop Maker or FACS screening services available.

\section{Drop everything and call us today. 617-868-2399}

\section{One cell Systems, Inc.}

100 Inman Street

Cambridge, MA 02139

617-492-7921 fax

microdrop@aol.com

READER INQUIRY NO. 668

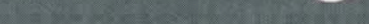

